\title{
Macro Prudential Supervision in the Open Economy, and the Role of Central Banks in Emerging Markets
}

\author{
Joshua Aizenman
}

Published online: 17 February 2010

(C) The Author(s) 2010. This article is published with open access at Springerlink.com

\begin{abstract}
In this paper we explore lessons from the global liquidity crisis pertaining to the prudential supervision role of central bank in an open economy. The crisis validates the need for external debt management policy in emerging markets. Hoarding international reserves (IR) is a potent self-insurance mechanism. However, it is associated with relatively high costs and is also less efficient in absence of assertive external debt management policies. In the presence of congestion externalities associated with deleveraging, optimal external borrowing-tax-cum-IRhoarding-subsidy reduces the cost as well as the scale of hoarding IR.
\end{abstract}

Keywords Prudential supervision · Deleveraging $\cdot$ Congestion externalities · External debt management

JEL Classification $\mathrm{F} 15 \cdot \mathrm{F} 31 \cdot \mathrm{F} 43$

\section{Introduction}

Macro prudential supervision and the role of central banks have evolved substantially over the past few decades. This evolution reflects learning by doing, reaction to crises, as well as changes in our understanding of prudential supervision. The Laissez Faire view of the role of central banks has gravitated from a "benignneglect" view of economic stabilization (Lucas 1987, 2003) towards the Taylor rule, wherein monetary policy is set by a rule rather than discretion. To recall, about two

This report was compiled with the financial support of the Bank of Korea. I would like to thank George Tavlas for his comments and suggestions. I also gratefully acknowledge the hospitality of the BOK, and the research assistance of Rajeswari Sengupta. Any views expressed herein are those of the author and do not reflect the views of the Bank of Korea or of the National Bureau of Economic Research.

\footnotetext{
J. Aizenman $(\bowtie)$

Economics Department, E2 and the NBER, University of California, Santa Cruz, Santa Cruz, CA 95064, USA

e-mail: jaizen@ucsc.edu
} 
decades ago Robert Lucas showed that the costs of business cycles in a calibrated macroeconomic model are trivial, implying that there may be little role for central banks' stabilization policies or for fiscal policy. In the early 1990s, Taylor's influential paper surmised a simple rule as a plausible guide for central banks' policies (Taylor 1993). This happened against the background of a remarkable decline in macroeconomic volatility and cost of risk during the 1990s and early 2000s, a trend that has hence been referred to as "the great moderation." The "great moderation" induced observers to presume the beginning of the end of costly business cycles. Key policy makers, led by Fed's Chair Alan Greenspan, advocated a non-activist role of central banks. The implication was that central banks should refrain from policies aimed at curbing the appreciation of real assets ("asset inflation"), focusing instead on "goods inflation." "This reflected the spirit of late 1990s and early 2000s, when the presumption was that private intermediation with minimal regulatory oversight provide superior results. The view fitted well with Lucas' take on the cost of the business cycles, and the difficulty in identifying 'bubbles' in real time.

The Lucas assessment of business cycle costs was challenged by Ramey and Ramey (1995) and other studies. They had consistently found that volatility exerts a significant negative impact on long-run (trend) growth, which is exacerbated in poorer countries. $^{2}$ In a similar vein, studies found that the 1997-8 crisis had lingering adverse growth effects on affected countries (Cerra and Saxena 2008). The narrow view of central banks' roles have been seriously challenged by the global liquidity crisis of 2008-9, propagating a rigorous debate about the desirable course of prudential regulation and central bank policies. By force of history and by virtue of learning by doing, the pendulum is now shifting towards a more nuanced view. The emphasis is switching towards recognizing central banks' responsibility in implementing prudential regulations and policies aimed at reducing volatility and susceptibility of economies to crises. ${ }^{3}$

\footnotetext{
${ }^{1}$ To recall, former Fed Chairman Alan Greenspan advocated a hands-off approach to asset prices during the U.S. expansion that lasted 6 years until December 2007. He said it was easier to clean up the mess of a bust than to spot bubbles and that monetary policy was too blunt to deflate them. "As events evolved, we recognized that, despite our suspicions, it was very difficult to definitively identify a bubble until after the fact - that is, when its bursting confirmed its existence. Moreover, it was far from obvious that bubbles, even if identified early, could be pre-empted short of the central bank inducing a substantial contraction in economic activity - the very outcome we would be seeking to avoid." March 2, 2005, to House Budget Committee.

2 See Ramey and Ramey (1995) for a detailed study of OECD and developing countries and Aizenman and Marion (1993) for a study dealing with developing countries.

${ }^{3}$ A recent Bloomberg report exemplifies the 2008-9 crisis Zeitgeist:

\begin{abstract}
Central bankers from Washington to Oslo are taking greater account of accelerating asset prices to avoid the policy mistakes that inflated two speculative bubbles in a decade and led to the worst financial crisis since the Great Depression. A month after warning that property prices are rising 'probably excessively,' Norges Bank Governor Svein Gjedrem is set to increase interest rates on Oct. 28. Reserve Bank of Australia Governor Glenn Stevens cited costlier real estate as a reason for raising rates 3 weeks ago.... The question now is 'whether the interest rate should respond to asset prices and the financial situation more generally, and there is a strong argument that the answer is yes,' Bank of Israel Governor Stanley Fischer said Aug. 21.
\end{abstract}

Central Banks Hitting Assets Question Greenspan View, Bloomberg, Simon Kennedy, October 26, 2009. http://www.bloomberg.com/apps/news?pid=20601087\&sid=aIYvRd5Zjf2Y 
In this paper, we take such a nuanced view of the role of central banks. The fact that ex-ante we are unable to identify "a bubble" or a crisis does not negate the role of policies aimed at reducing the probability and the adverse impact of unsustainable real appreciations. Applying Bayesian logic, policy makers should react to signals that indicate heightened probability of a crisis, even if there is no way of knowing a-priori the timing and depth of the crisis. The intellectual underpinning of this approach involves costly financial intermediation. In order to finance investment, firms can turn to external sources, such as bank loans, equity or corporate bonds, or rely on internal funds, such as retained earnings. However, capital markets tend to be thin or practically non-existent during sudden stops and deleveraging crises, thereby constraining investment to be funded internally or by banks. As was shown by Townsend (1979) and Bernanke and Gertler (1989), more costly verification and enforcement of contracts combined with higher economic volatility increase the cost of external funds, thereby reducing investment. When recessions occur, internal funds dry up leading to a greater contraction of investment than would occur with well-functioning capital markets. This in turn induces concavity in the association between shocks and investment. Under such circumstances, more volatile shocks would reduce average GDP and, potentially, the economic growth. This mechanism is only one plausible way of accounting for possible adverse effects of volatile shocks on economic performance. ${ }^{4}$ Taking this perspective, central banks should charter policies that would reduce the impact of volatility on economic performance.

In the next section we overview prudential supervision in emerging markets (EMs) exposed to capital inflows, and deleveraging vulnerabilities. We identity conditions under which prudential supervision that reduces economic volatility has sizable beneficial effects. We end the paper with a discussion linking our results to recent policy trends.

\section{Prudential supervision, capital inflows, and deleveraging vulnerabilities}

Dealing with financial inflows remains a challenge facing all central banks. While this is not news for Emerging Markets (EMs), the current global liquidity crisis clearly illustrated that financial inflows put to test the regulation capacities of all countries. This has also been recognized by Fed's Chair Ben Bernanke:

"A lot of capital flowed" into countries such as the U.S., "which would not be a problem if we had invested and managed that money appropriately"... "But evidently, we were not able to do that." Both private and regulatory riskmanagement mechanisms "were overwhelmed." Oct. 19, 2009, Bloomberg.

The mixed blessing associated with capital inflows is driven by the principle of the second best. Financial opening improves welfare in a situation when restricting intertemporal trade across countries is the only distortion. At the same time, financial

\footnotetext{
${ }^{4}$ Other mechanisms accounting for the negative association between economic volatility and growth include: weak institutions and the investment channel; incomplete capital markets and sovereign risk; volatility, income inequality, and growth; divisive politics, inefficient taxation and procyclical fiscal policy, etc. See Aizenman and Pinto (2005, Lead Chapter) for an overview of these issues [at http://www1. worldbank.org/economicpolicy/mv/mvcguide.html]
} 
opening and capital inflows may magnify other distortions, possibly reducing welfare. These distortions include moral hazard, costly deleveraging, and a host of related agency problems. ${ }^{5}$ A mechanism to reduce exposure to sudden stops and costly deleveraging associated with financial integration has been the widespread hoarding of international reserves (IR) by EMs. The experience of Korea during the last 15 years outlines the contours of the debate about self-insurance by means of hoarding reserves. To recall, following the 1997-8 East Asian crisis, Korea embraced financial integration, buffered with large hoarding of IR. The large stockpiles of IR provided Korean authorities with precautionary savings to cushion against sudden stops and deleveraging. Figure 1 provides an overview of these trends (1992-2008), tracing the short run and long run external debt to GDP ratios, share of foreign ownership of equities of firms listed on the Korean stock exchange, and the IR/GDP ratio in Korea. Korea's financial integration started gradually in the early 1990s and accelerated in the aftermath of the East Asian crisis. This integration process led to rapid increase in foreign ownership share of Korean stock market, from less than 5\% in 1992 to more than 40\% in 2004. Korea's IR/GDP hovered around $5 \%$ before the $1997-8$ crisis. However, the financial upheaval triggered by the crisis induced a major change in Korea's IR hoarding policy. By 2004, IR reached more than $25 \%$ of Korean GDP, exceeded twice Korea's short term external debt, and were greater than Korea's total external debt. ${ }^{6}$ Korea's reserves in 2004 exceeded more than half a year of its imports, well above the yardstick for IR used during the Bretton Woods period. ${ }^{7}$

Less than 10 years after the 1997-8 East Asian crisis, Korea's IR/GDP ratio seemed more than adequate by conventional yardsticks. Indeed, observers have been raising questions about the growing costs of stockpiling these reserves. Some authors assert that the level of IR in EMs, including Korea, potentially exceed the social optimum [see Jeanne and Ranciere (2005)]. ${ }^{8}$ A broader self-insurance view is that IR provide a buffer, both against deleveraging initiated by foreign parties, as well as the sudden wish of domestic residents to acquire new external assets, i.e., "sudden capital flight" [see Calvo (2006) and Obstfeld et al. (2008)]. ${ }^{9}$ Having said this, the sense of possible abundance of IR in Korea was challenged following the sizable increase in Korea's external debt during 2005-2008. The Korean external short term debt/GDP ratio increased from $7.5 \%$ in 2004 to $20 \%$ in 2008 , while the

\footnotetext{
${ }^{5}$ See Aizenman (2004) for an overview of the debate.

${ }^{6}$ I am grateful to Yeonho Lee for sharing the data. See Aizenman et al. (2007), where we show that the 1997-8 crisis led to structural changes in the hoarding of Korea's IR. The Korean monetary authority seemed to give much greater attention to a broader notion of 'hot money,' inclusive of short-term debt and foreigners' shareholding.

${ }^{7}$ While focusing on IR/GDP instead of IR/Imports is arbitrary, it allows for a comparison overtime during decades when financial factors gained importance in explaining the patterns of hoarding IR. Prior to the financial integration, the demand for reserves provided self-insurance against volatile trade flows. However, financial integration added the need to self-insure against volatile financial flows. By the nature of financial markets, the exposure to rapidly changing demands for foreign currency triggered by financial volatility exceeds the one triggered by trade volatility [see Aizenman and Lee (2007)].

${ }^{8}$ Estimating the benefits of hoarding IR between 2000 and 2005 in terms of crisis prevention, Jeanne (2007) concluded that, on average, the cost of IR accumulation exceeded the benefits by a factor of three. ${ }^{9}$ The high positive co-movement of international reserves and M2 is consistent with the view that the greatest capital-flight risks are posed by the most liquid assets, i.e., by the liquid liabilities of the banking system as measured by M2 [see Obstfeld et al. (2008) for further discussion].
} 


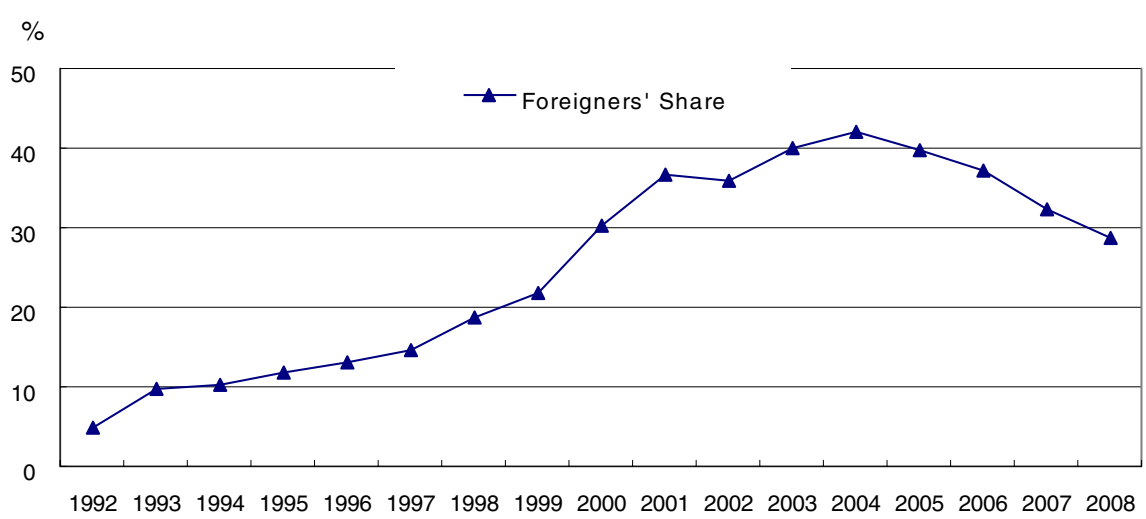

(a) Foreigner's share of Korea's equity market

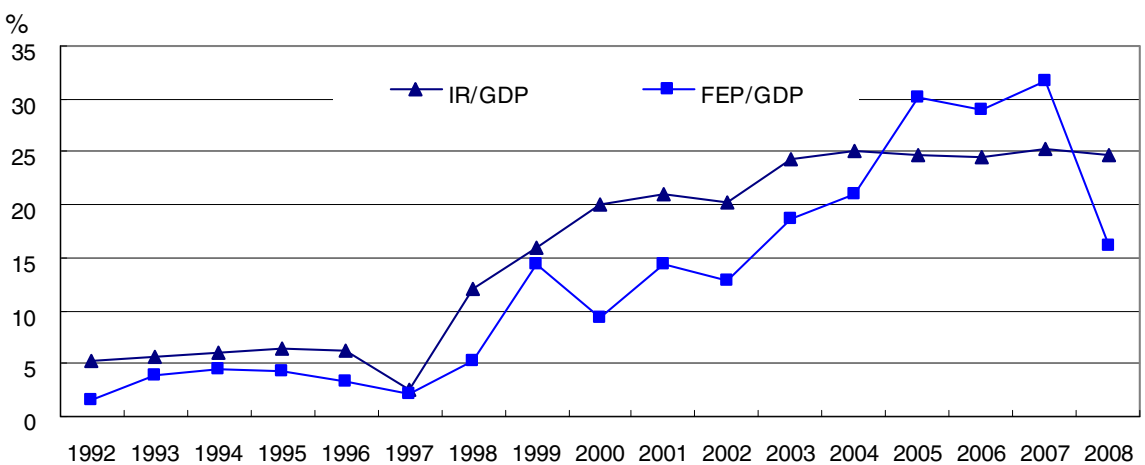

(b) IR/GDP and foreigners' equity position/GDP

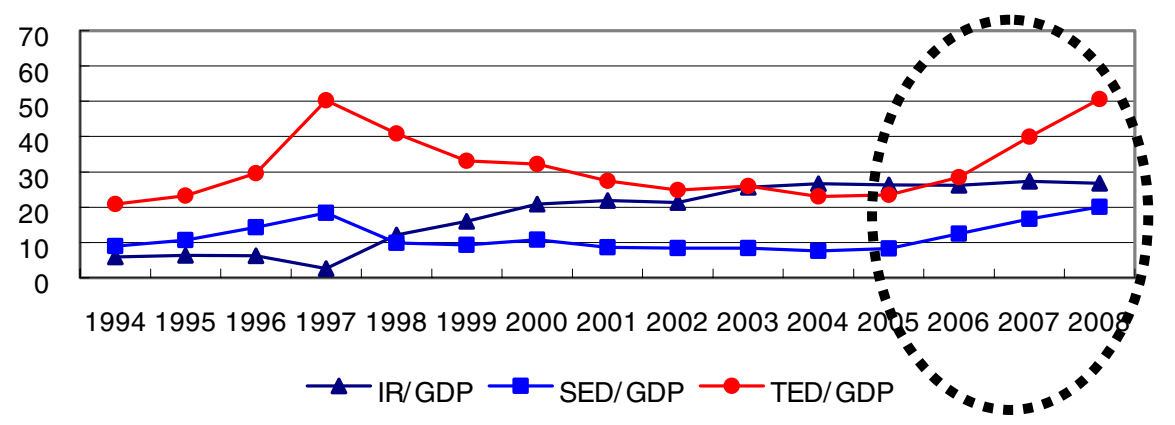

\section{(c) IR/GDP and External Debt/GDP}

Fig. 1 South Korean Experience, 1994-2008, IR/GDP, External Debt/GDP, and foreigners' equity/GDP. $\mathrm{FEP}=$ foreigners' equity position based on market value of foreigners' shareholdings. SED = short-term external debt, TED $=$ total external debt 
overall external debt/GDP ratio increased during that period from $23 \%$ to $50 \%$, without any significant change in IR/GDP. This drastic increase has been attributed to exposure to short term inflows of hot money associated with Yen financed carry trade, and the large increases in foreign borrowing by foreign branches in Korea via transactions with their respective overseas headquarters, representing profitability of interest rate arbitrage. The rapid increase of external debt illustrates the hazard associated with an absence of a pro-active external debt management policy which has been neglected perspective. Similar challenges have been experienced by other EMs, including Brazil, a country that has been executing a more proactive policy of external debt management than Korea, under similar circumstances.

The onset of the current global liquidity crisis and the ensuing deleveraging clearly illustrated the fragility of Korea's balance-sheet. During the first stage of the 2008-9 global liquidity crisis, Korea's IR dropped by roughly $\$ 60$ billion in half a year, a decline of about $25 \% .{ }^{10}$ The Korean government unveiled a bailout package in the second half of 2008, committing to use Korea's IR to support its banking system. The principal element of the package was a $\$ 100$ billion, 3-year government guarantee for banks' foreign debt. This sum was more than sufficient to cover Korean banks' foreign debt maturing by June 2009. The latter has been estimated by the Korean Ministry of Strategy and Finance to be about $\$ 80$ billion. Yet, observers noted that, despite the large hoarding of IR used to finance the bailout package, market concerns did not abate.

Similar guarantees had failed to allay fears of financial meltdown at the beginning of the Asian crisis in 1997 and they failed again. As in 1997, the market reactions were indifferent. Only when Korea secured a swap line amounting to $\$ 30$ billion from the Fed on October 30 the foreign exchange market settled down somewhat, but not very long. The foreign exchange rate shot up to 1,509 won per dollar 3 weeks after the swap had been announced, which was apparently not enough to remove uncertainties surrounding Korea's ability to service its foreign debt. Korea also managed to arrange won-local currency swaps with the central banks of both China and Japan, each amounting to an equivalent of $\$ 30$ billion on December 13. Only when it was made clear that the Fed would renew the swap agreement, foreign investors' confidence in the Korean economy improved and stability in the foreign exchange market returned toward the end of the first quarter of 2009."

Yung Chul Park (2009)

Looking beyond Korea, other EMs cushioned their adjustment to the global financial crisis by a combination of exchange rate depreciation and partial depletion of their IR. Yet, after the first phase of adjustment, central banks have been reluctant to draw down their IR further. It is possible that this reluctance reflected the fear that further depletion of IR may signal growing vulnerability, a potential adverse externality arising from a tendency to "keep up with the Joneses' IR". This refers to the apprehension of a country that reduction of its IR/GDP ratio below the average of its reference group may increase its vulnerability to deleveraging and sudden stops [see Cheung and Qian (2009) for evidence on "keeping up with the Joneses'

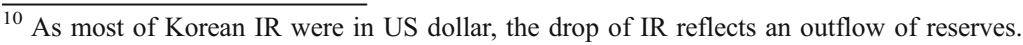


IRs" in context of East Asia]. These factors suggest a greater demand for regional pooling arrangements and swap lines (see Rajan et al. (2005)), as well as possible new roles for International Financial Institutions. Yet, short of a major overhaul of the global financial architecture, proper management of external debt of a country remains a key challenge of EMs. While moving to financial autarky is overkill, ignoring the benefits of external debt management has proven to be very costly.

Figure 2 portrays the IR dynamics during the first 9 months of the crisis in Korea, India, Russia, Poland and Malaysia, July 08-March 09, reporting the ratio of IR (US dollar) relative to their level in July $08 .{ }^{11}$ Central banks used a share of their IR in first few quarters of the crisis to finance deleveraging pressures, thereby mitigating currency depreciation. Yet, after losing not more than one-third of their initial stocks of IR, Korea, India, Russia and other EMs became more averse to further drawing down their IR. The inverted S curves reported in Fig. 2 depict the decelerating IR outflows within 6 months, well before the end of the crisis. This deceleration trend is consistent with the "fear of losing IR" - the wish to preserve a buffer against leaner times. The choice of the speed of drawing-down accumulated IR is a delicate one. It hinges on the anticipated future course of the global economy, domestic adjustment capacity, and the degree of financial integration of the country in question. For instance, the trade-offs for a country such as India differ from those facing Chile. India is relatively less integrated with the global financial system than Chile, and the Indian government has less room for fiscal adjustment due to its significant and growing fiscal deficit. Brazil, Chile and other EMs, on the other hand, have preferred to adjust to the current crisis mostly through exchange rate depreciation. It is possible that the latter group of EMs have been saving their IRs for leaner years to self-insure against potential prolonged periods of downward pressure on their terms of trade.

Further insight about the 'fear of losing IRs' can be gained by looking at the differential patterns across all EMs of using IRs during the crisis. To recall, investigating the patterns of exchange rates, interest rates and IR during 1970-1999, Calvo and Reinhart (2002) inferred the prevalence of the "fear of floating". Countries claiming that they allow their exchange rates to float, mostly do not. Instead, the authorities frequently attempt to stabilize the exchange rate through direct intervention in foreign exchange market and open market operations. The fear of floating may also provide an interpretation for the massive hoarding of IR during the last 10 years by EMs and other developing countries. Alternative explanations of IR hoarding however include the precautionary and/or mercantilist motives (Aizenman and Lee 2007), as well as the reincarnation of the Bretton Woods system (Dooley et al. 2009). The present crisis imposes daunting challenges to EMs. The "flight to quality," deleveraging and the rapid reduction of international trade affected EMs from mid 2008 onwards, thereby testing their adjustment capabilities. While in several earlier crises episodes, EMs were forced to adjust mostly through rapid exchange rate depreciation, the sizable hoarding of IR during the late 1990s and early 2000s provided the same countries with a richer menu of choices.

\footnotetext{
${ }^{11}$ The dominance of the US \$ in the composition of reserves implies that most of these changes reflect IR outflows [due to data limitations, we are unable to control valuation effects].
} 


\section{IR dynamics during the crisis}

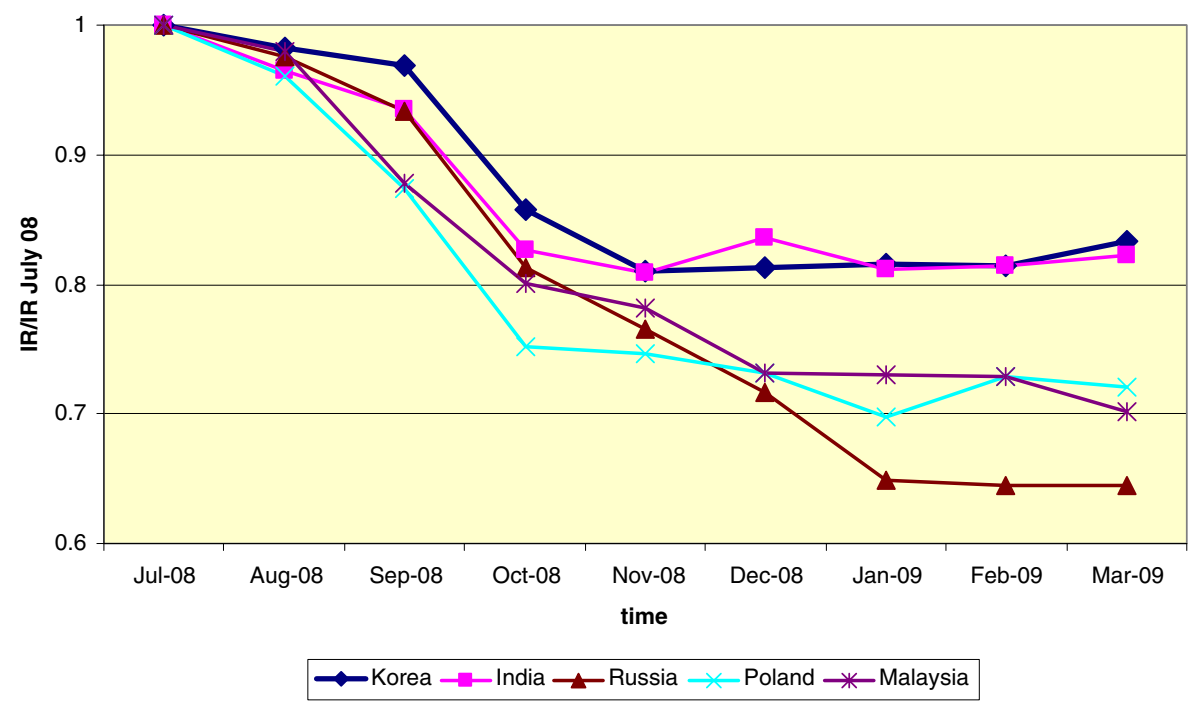

Fig. 2 International reserves and the deleveraging crisis, 8-08 to 3-09; South Korea, India, Russia, Poland and Malaysia

Aizenman and Yi (2009) look at the degree to which the large hoarding of IR "paid off," during the current crisis in terms of allowing EMs to adjust by drawing down their IR. Their study explores the adjustment of 21 EMs during the window of the current crisis and reveals a mixed and complex picture. ${ }^{12}$ Regression analysis shows that EMs with large primary commodity exports, especially oil exports, experienced large IR losses during the current global crisis. Countries with a medium level of financial openness and a large short term external debt to GDP ratio also on average lost more of their initial IR holdings. Most of the countries that suffered large IR losses, started depleting their IR during the second half of 2008. Quite intriguingly, only about half of the EMs relied on significant depletion of their IR as part of their adjustment mechanism. The study proceeds by dividing the sample of EMs into two groups: countries that experienced sizable IR losses and countries that had either not lost IR or quickly recovered from their IR losses. The first group is defined as countries that lost at least $10 \%$ of their IR during the period of July $2008-$ February 2009 relative to their highest IR level. Among 21 EMs, 9 countries belong to the first group. ${ }^{13}$

\footnotetext{
${ }^{12}$ The EMs' sample is composed of the countries listed in the FTSE and MSCI emerging market list. It does not include Singapore and Hong-Kong because of their special economic structure, specializing in entrepôt services. In addition, due to the dramatic effect of the IMF's aid on Hungary's reserves changes, it has been excluded from the sample (Hungary's IR had increased nearly by half in the 2 months after the IMF's stabilization package was put in place). The study also excluded Morocco and Pakistan due to unavailability of the relevant data.

${ }^{13}$ Countries facing large losses in stocks of IR include Brazil (BRA), India (IND), Indonesia (IDN), Malaysia (MYS), South Korea (KOR), Peru (PER), Poland (POL), Russia (RUS), and Turkey (TUR).
} 
To gain further insight, Aizenman and Yi (2009) compare the pre-crisis demand for IR/GDP of countries that experienced sizable depletion of their IR, to that of countries that did not, and find differential patterns across the two groups. Trade related factors (such as trade openness, and the primary goods export/total export ratio, especially large oil export/total export) seem to be more significant in accounting for the pre-crisis IR/GDP levels of countries that experienced a sizable depletion of IR in the first phase of the crisis. These findings suggest that countries that internalized their large exposure to trade shocks before the crisis used their IR as a buffer stock in the first phase of crisis. The IR losses of these countries followed an inverted logistical curve. After a rapid initial depletion of IR, these countries reached within 7 months a markedly declining rate of IR depletion, and lost not more than one-third of their pre crisis IR. In contrast, in case of countries that refrained from a sizable depletion of IR during the first crisis phase, financial factors seem more important than trade factors in explaining the initial level of IR/GDP. The patterns of using IR by the first group of countries, and refraining from using IR by the second group, are consistent with the 'fear of losing reserves'. Such a fear may reflect a country's concern that dwindling IR may signal greater vulnerability to run on its currency, thereby triggering such a run on its remaining reserves. This fear may be related to a country's apprehension that, as the duration of the crisis in unknown, depleting IR quickly may be sub-optimal. Rapid depletion of its reserves exposes a country to the risk of a swift and, therefore, potentially economically and politicallydifficult adjustment in its real economy.

These findings suggest that there exists a clear structural difference in the precrisis demand for IR between EMs that were willing versus those that were unwilling to spend a sizable share of their IR during the first phase of the 2008-9 crisis. Trade related factors are more significant in accounting for the pre-crisis IR level of the countries that were willing to accept a sizable depletion of their IR in the first phase of the crisis, in line with the buffer stock interpretation of demand for IR. Countries that depleted their reserves in the first phase of the crisis refrained from drawing their IR below a two-third of the pre-crisis level. The majority of these EMs used less than one-fourth of their pre crisis IR. Countries whose pre crisis demand for IRs was more sensitive to financial factors, refrained from using IR altogether and achieved external adjustment through larger depreciations of their currencies than those put in place by the countries that were sensitive to trade factors. The results found by Aizenman and Yi (2009) suggest that the adjustment of EMs during the on-going global liquidity crisis has been constrained more by their fear of losing IR than by their fear of floating.

Countries' choice of currency depreciation instead of reserve depletion also suggests that some opted to revisit the gains from financial globalization. Earlier research suggests that EMs that increased their financial integration during the 1990s and mid 2000s, accumulated IRs due to precautionary motives, to obtain self insurance against sudden stops and deleveraging crises. Yet, the on-going global crisis suggests that the levels of IR required in order for this self-insurance to work may be comparable to that of a country's gross external financial exposure [see Park (2009) analyzing Korea's challenges during the crisis]. In these circumstances, prudential supervision that would tighten the link between short-term external borrowing and hoarding IR would mitigate the excessive exposure to deleveraging 
risks induced by short-term external borrowing. This objective can be accommodated by a Pigovian tax-cum-subsidy scheme that induces domestic agents to internalize the externality associated with external borrowing and a deleveraging crisis. A virtue of such a scheme is that the optimal borrowing tax funds the optimal subsidy on hoarding IR, thereby mitigating concerns about costly hoarding of large stockpiles of IR needed to self-insure against a deleveraging crisis.

\subsection{The fire sale deleveraging externality and the case for a Pigovian tax-cum-subsidy scheme}

As is well appreciated by now, bank intermediation facilitated by short-term external borrowing in hard currency exposes the economy to the risk of sudden stops and deleveraging crisis. Such a crisis frequently induces costly premature liquidation of tangible investment. If IR are not plentiful, a deleveraging crisis induces a large number of banks to simultaneously liquidate investments. Such liquidation in turn depresses the selling price of tangible capital, thereby increasing the cost of deleveraging, i.e. the fire-sale effect. If foreign currency reserves are limited, the deleveraging would tend to cause a bidding-up of the price of foreign currency, requiring each bank to liquidate more of its investment to obtain the foreign exchange required as a result of a given amount of deleveraging. While each bank takes potential fire-sale prices as given, taken together, their actions as a group induce the fire sale prices. This leads to a fire-sale externality [see Krugman (2000) on the experience of Korea in the 1997-8 crisis]. ${ }^{14}$ This fire-sale externality reduces the marginal social benefit of borrowing below the private benefit, and increasse the marginal social benefit of hoarding IR above the private one. Aizenman (2009) outlines the case of supplementing hoarding IR with a Pigovian tax-cum-subsidy scheme. Properly designed, the scheme reduces the distortion i.e. external borrowing, thereby inducing borrowers to co-finance precautionary hoarding of IR by means of the borrowing tax.

To recall, Eichengreen et al. (2003), and the related balance sheet literature showed that external debt associated with maturity and currency mismatches increases the downside risk of costly sudden stops. Greater balance sheet exposure frequently entails higher real depreciation triggered by deleveraging, greater distress of the domestic banking system, and ultimately higher output costs of a sudden stop and deleveraging crisis. If most foreign and domestic agents are price takers, each ignores its marginal impact on increasing the expected cost of such a crisis. This in turn entails an externality akin to "congestion", calling for a Pigovian tax-cumsubsidy scheme. In the Appendix we overview a minimal model seeking to explain the optimal self-insurance offered by IR in mitigating the output effects of liquidity shocks and the gain from the Pigovian tax-cum-subsidy scheme. The structure of the model is akin to that of Diamond and Dybvig (1983). Investment in a long term project is undertaken prior to realization of liquidity shocks. A key element of the model is that the cost of deleveraging increases with the aggregate deleveraging pressure. Under such circumstances, competitive financial intermediation induces

\footnotetext{
${ }^{14}$ Bhattacharya and Gale (1987) investigated this externality in banking, and Caballero and Krishnamurthy (2004) in international finance.
} 
each bank to overlook the impact of its deleveraging on the deleveraging costs of all other banks, thereby inducing a fire-sale macro externality.

Figure 3 summarizes this discussion. It plots the expected marginal productivity $(E M P)$ of investment funded by external borrowing, drawn for a given level of IR. Curve $E M P_{D}^{P R}$ corresponds to conditions facing the atomistic entrepreneur in absence of borrowing taxes. The debt threshold level $\widetilde{D}$ is the lowest external debt associated with possible liquidation pressure at times when the deleveraging shock would exceed IR. A further increase in external debt increases the expected cost of liquidation. The expected cost of external funds is depicted by the horizontal line (the weighted average of the risk free real interest rate $r_{f}$, and the real return on unliquidated deposits financing the investment, $\rho$ ). In the absence of tax-subsidy policies, external borrowing is given by $D_{0}$, equating the expected private marginal productivity of investment with the expected cost of funds. Curve $E M P_{D}^{S O}$ is the expected social marginal benefit of borrowed funds. It coincides with $E M P_{D}^{P R}$ as long as the probability of costly liquidation is zero (for $D<\widetilde{D}$ ). For $\widetilde{D}<D$, the planner's curve $E M P_{D}^{S O}$ is below the entrepreneur's curve $\left(E M P_{D}^{P R}>E M P_{D}^{S O}\right)$ because it takes into account the negative fire-sale externality associated with marginal borrowing. For given initial IR, the optimal external borrowing is $\widehat{D}$, well below $D_{0}$. The fire sale externality is given by the dotted line $C E$. The optimal borrowing tax is defined by the externality. Note that Fig. 3 is a partial equilibrium treatment drawn for a given level of IR. A similar figure can be drawn for the bank's and the planner's demands for IR. In comparison to the initial no borrowing tax equilibrium, the impact of the optimal tax and subsidy is to reduce the distorted activity. I.e., external borrowing drops, and IR hoarding is co-financed the by taxing the activities that expose the economy to the need to self-insure. ${ }^{15}$

It can be shown that, even if the policy maker is prevented from implementing tax policies that raise net revenues, Laissez Faire is not optimal. In these circumstances, the fire-sale externalities can be dealt with by dynamic reserve requirements imposed on external borrowing. Such a policy should apply uniformly to all banks operating in the EM, including branches affiliated with foreign banks. Recalling Rodrik (2006) may help put this discussion in a broader context. Rodrik (2006) evaluated the costs and benefits of hoarding IR and concluded that EMs "have over-invested in the costly strategy of reserve accumulation and under-invested in capital-account management policies to reduce their short-term foreign liabilities." The proposed tax-cum-subsidy scheme described above outline a strategy in the spirit of Rodrik's assessment, tightening the links between hoarding IR and managing short-term foreign liabilities.

\footnotetext{
15 The design of the FDIC deposit insurance scheme in the US may be viewed as generating outcomes similar to those of the tax-cum-subsidy scheme outlined in this paper. The FDIC charges insurance premiums on bank deposits at a rate that ideally should reflect the riskiness of banks' investments. The insurance premium is akin to a tax on banks' borrowing. The provision of insurance by the FDIC acts in ways similar to subsidizing hoarding liquid resources to provide self-insurance. As with any insurance scheme, care should be taken to deal with the possibility of moral hazard. See Levi Yeyati (2008) for the moral hazard challenge facing the central bank in a dollarized economy.
} 


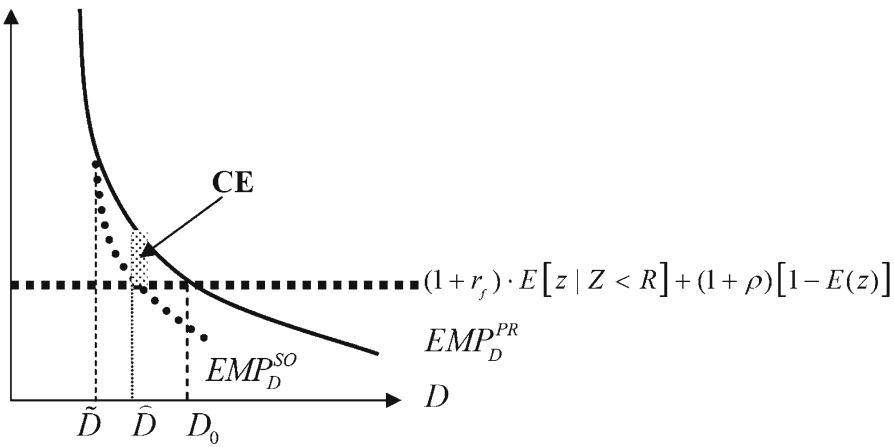

Glossary

$E M P_{D}^{P R}=$ the expected private marginal productivity of investment. $\quad E M P_{D}^{S O}=$ the expected social marginal benefit of borrowed funds. The expected cost of external funds is the horizontal line.

$C E$ = the fire sale externality. $\tilde{D}=$ the lowest external debt associated with possible liquidation pressure.

$D_{0}=$ Laisse $z$ Faire equilibrium debt. $\widehat{D}=$ optimal debt.

Fig. 3 Sudden stop and external borrowing: the case of fire-scale congestion externalities and optimal external borrowing tax

\section{The recent experience}

In the current context, in absence of a deep reform of global financial architecture, EMs remain exposed to sudden stops and deleveraging crises. The proposed external borrowing tax-cum-reserves hoarding-subsidy, if enacted before the inflow of capital begins, would facilitate more sustainable financial integration. A recent example of a country's experimenting with such policies is Brazil, which had a tax of $1.5 \%$ on capital inflows into the bond market until the onset of the crisis. Beginning October 20, 2009, Brazil enacted a $2 \%$ tax on portfolio investment, i.e. capital destined for investment in shares and bonds. The tax must be paid at the time of the initial currency exchange. This tax follows a dramatic increase in inflows of hot money, that induced appreciation of the Real from about 2.4 Real $/ \$$ in November 2008 to $1.71 \mathrm{Real} / \$$ in mid October 2009, shortly before the tax announcement. By now, the fastest growing countries in Asia [China and India] and Latin America [Brazil] are applying regulation and various taxes on inflows of capital - a policy that implicitly subsidizes the cost of the sizable stocks of IR held by these countries. Arguably, such policies reduced the exposure of these countries to the deleveraging crisis of 2008-9 and may reduce the costs of the renewed inflows of hot money. ${ }^{16}$ This conjecture is supported by Fig. 4, reporting the net

\footnotetext{
${ }^{16}$ Attempts to tax external borrowing include the Chilean scheme of the late 1990s. While the results of this scheme were debatable, one should keep in mind that this policy was not meaningfully tested in Chile, as the counterfactual experiment was impossible to implement. Chile was the best performing country in Latin America during the time when this policy was applied, and no sudden stop crisis affected it during that time. It remains debatable whether the relative stability of the Chilean economy was due to good luck, good institutions, or/and good policies [for further discussion, see type see Edwards (2000) and Cowan and de Gregorio (2005)]. Indeed, the recent experience of Brazil, China and India is probably the best case study of possible impact of external balance sheet management at times of heightened exposure to a sudden stop and deleveraging crises.
} 

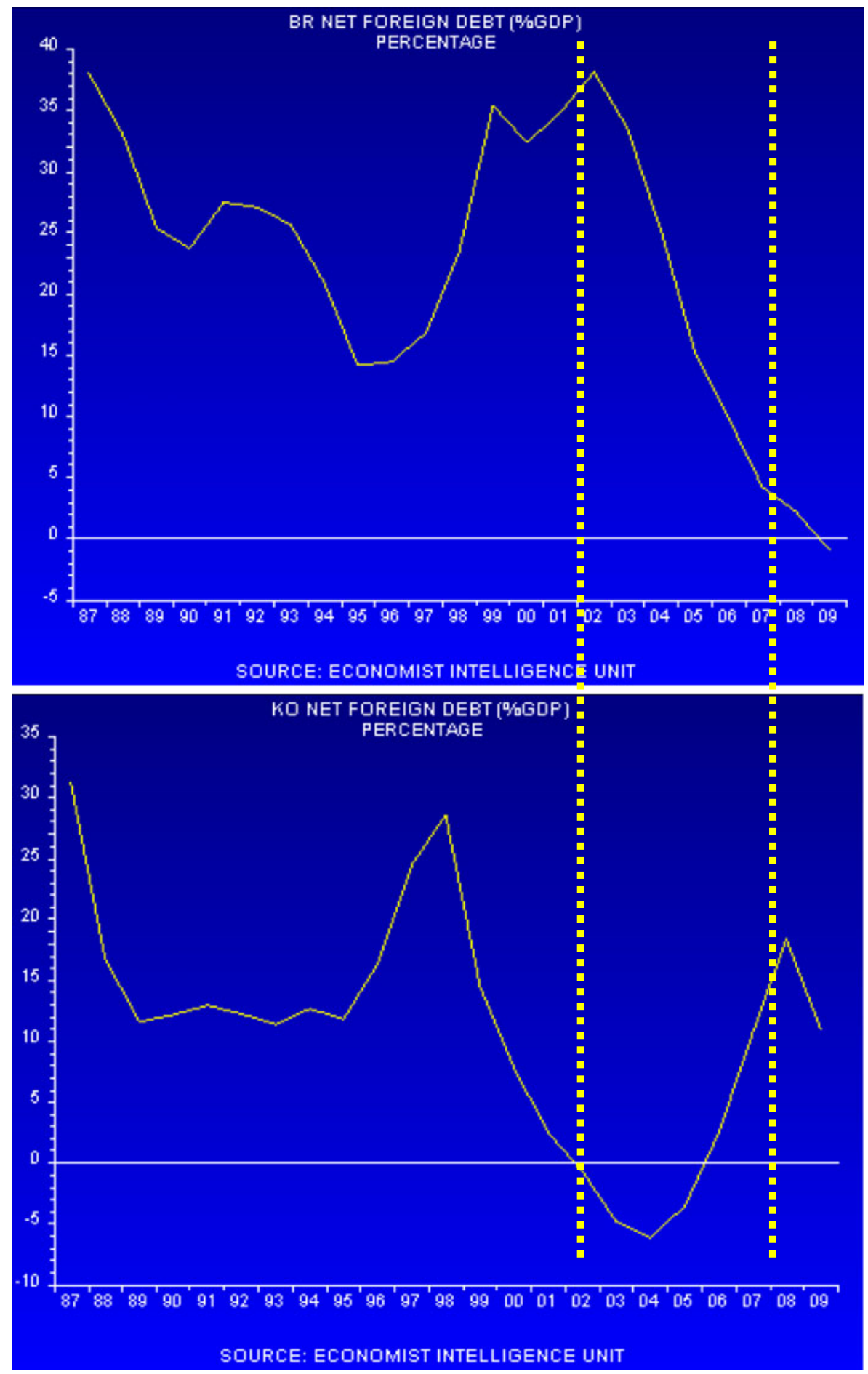

Fig. 4 Net foreign debt/GDP of Brazil (left panel) and Korea (right panel), 1987-2009 
foreign debt exposure of Brazil (top panel) and South Korea (lower panel) during the period of 1987-2009. Brazil's net exposure declined from about 35\% in 2002 to about zero in 2008, whereas Korea's net exposure increased from about $0 \%$ in 2002 to $20 \%$ in 2008 .

The resumption of inflows to Emerging Markets and the hoarding of IR may provide the illusion that 'all is well.' Yet, as the crisis of 2008-9 clearly illustrated, hoarding IR remains a costly option, which may not be sufficient unless it is coupled with assertive policies directed at managing and mitigating aggregate exposure to external debt. As the Korean experience prior to the 2008-9 crisis showed, large hoarding of IR without more active balance-sheet management may increase the vulnerability associated with massive build up of short and intermediate run external debt. Alternatives to massive hoarding of IR include a deeper use of swap lines and IR pooling arrangements as well as channeling reserves into potentially higher yielding but riskier assets, such as those managed by Sovereign Wealth Funds. While potentially useful, these alternatives are not a panacea. Swap lines are typically of short duration, and are limited by potential moral hazard considerations. Diversification by means of Sovereign Wealth Funds exposes the economy to the risk that value of the fund may collapse precisely at the time when hard currency is needed to fund deleveraging as has been the case during the 2008-9 global liquidity-crisis.

The virtue of the tax-cum-subsidy scheme is that it would reduce the taxpayer's burden of financing the cost of hoarding IR, and will mitigate the balance sheet exposures associated with unchecked international portfolio flows. Such a scheme may also mitigate the political demand in EMs to spend the accumulated reserves. Taxing external borrowing would reduce the needed reserves. Such a tax-scheme would also help fund the accumulation of IR by activities that expose the economy to the need to self-insure.

The logic of our discussion may be viewed as an open economy extension of the growing recognition that the current global financial crisis calls for changes in the operations of central banks. In his presentation at the recent Jackson Hole symposium Charles Goodhart pointed out:

"So, rather than sticking to the banking paradigm, liquidity provision should be assessed within an insurance paradigm. Almost all insurance generates moral hazard; liquidity insurance is, clearly, no exception. The answer in general has been to set premia in fair accordance with the risks being run by the assured so that the provision of insurance at least breaks even for the insurer, in this case the Central Bank and through it the taxpayer.

What this should then involved in a continuing, and regular, measurement of the risks that the behaviour of the insured, both individually and as a system, are imposing on the insurer, i.e. the Central Banks, as the ultimate provider of liquidity, and the application of sanctions on such behaviour, sanctions that become tougher as the risks worsen. Both the calculation of such liquidity risk measure(s) and the design of the appropriate form and structure of sanctions are difficult, but both need to be done, and soon."17

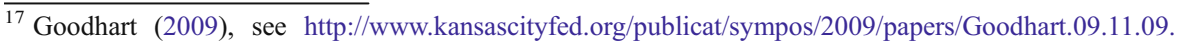
pdf for the full text.
} 
Goodhart's discussion is in line with the need for central banks to focus on "muddling through" the varying challenges they face as a result of the provision of liquidity insurance to systemic agents. In contrast to Alan Greenspan's seductive "market-stabilizing private regulatory forces" doctrine prevalent in the 1990s and 2000s, wherein central banks' role in active policies was muted, the current crisis has clearly brought to the fore the necessity of active macroeconomic supervision. While most of the discussion generated by the crisis has so far focused on the OECD economies (typically in the context of a closed economy), EMs remain exposed to unique challenges associated with external debt management. This paper illustrates that a proper external borrowing tax-cum-hoarding IR subsidy improves the efficiency of the economy by reducing the cost of insurance schemes provided by central banks in emerging market economies.

\section{Appendix}

In this Appendix we review the key building blocks of the analytical framework that explains the welfare gains from the external borrowing tax-cum-hoarding IR subsidy scheme. The structure of the model is akin to that of Diamond and Dybvig (1983). Investment in a long term project is undertaken prior to realization of a random liquidity shock. ${ }^{18}$ The liquidity shock may force costly liquidation of the earlier investment thereby reducing second period output. Since our focus is on developing countries, we assume that banks do all of the financial intermediation, relying on a debt contract. We simplify further by assuming that there is no separation between the bank and the entrepreneur. The entrepreneur is the bank owner and uses the bank to finance the investment.

At the beginning of period 1 entrepreneurs fund investment by external borrowing $D$ to finance planned second period capital, $K_{2, p}$, and banks' reserves, $R ; K_{2, p}=D-R$. At the end of period 1, after the commitment of investment capital, a deleveraging liquidity shock $\mathrm{Z}$ materializes. A fraction $z$ of foreign lenders demands their deposits back, $Z=z \mathrm{D}$. Assuming away sovereign risk and bankruptcy constraints, the deleveraging shock is first met by selling international reserves. Any excess of the liquidity shock $\mathrm{zD}$ above reserves $\mathrm{R}$ is met by pre-mature costly liquidation of $M A X\{0, Z-R\}$. The liquidation reduces the second period capital from $K_{2, p}$ to $K_{2}$ at a rate that depends on the adjustment cost, $\theta$ :

$K_{2}=K_{2, p}-(1+\theta) M A X\{Z-R, 0\}$. Premature liquidation implies that the impatient depositors get their money back without any interest payment. Only patient depositors (i.e., lenders that wait until period 2) are paid interest rate $\rho$ upon the realization of the investment. Final output is produced at period 2. The second period output finances the repayment of outstanding debt left to maturity,

\footnotetext{
$\overline{18}$ Our model extends Aizenman and Lee (2007). It follows the tradition of Bryant (1980) and of Diamond and Dybvig (1983) in that the source of liquidity shock lies with the lender, rather than the borrower (Holmstrom and Tirole 1998). However, we refrain from modeling the process that leads to lenders' deleveraging. Abstracting from the question whether market-based liquidity insurance is available, we focus on the implication of large adjustment cost on the demand for reserves as self-insurance. That cost includes, but is not restricted to, the liquidation cost. In a similar vein, no distinction is made between the private sector and the monetary authority which maintains the stock of IR.
} 
$D(1-z)(1+\rho)$. Unused reserves hoarded in period $1, M A X\{R-Z, 0\}$, provide the bank with a risk free return in the second period, $\left(1+r_{f}\right) \operatorname{MAX}\{R-Z, 0\}$.

The discussion above focuses on the perspective of the representative bank that is assumed to be a price taker. The bank ignores the fire-sale effect, i.e. the bank's attempt to liquidate capital tends to depress the selling price of capital facing all banks. Aggregate liquidation requires each bank to liquidate more of its investment to fund a given deleveraging pressure, increasing thereby the liquidation cost, $\theta$. Specifically, we assume that the liquidation $\operatorname{cost}, \theta$, depends positively on aggregate liquidation by $n$ identical banks, $L Q$ :

$$
\theta=\theta(L Q), \theta^{\prime}>0, L Q=n \cdot D_{i} \operatorname{Max}\left[z-z^{*}, 0\right],
$$

where $D_{i}$ is the liquidation of the representative bank. For a representative bank, $L Q_{i}=D_{i} \operatorname{MAX}\left[z-z^{*}, 0\right]$. We denote by $\eta_{\theta, i}$ the elasticity of the liquidation cost with respect to the deleveraging by bank $\mathrm{i}, \eta_{\theta, i}=\frac{\partial \log \theta}{\partial \log \left[D_{i}\left(z-z^{*}\right)\right]^{*}}$. We assume a large enough number of identical banks, $n$, so that the deleveraging elasticity of each bank is negligible. Yet, the combined effect of all banks' deleveraging, $\eta \cdot \eta_{\theta, i}$, is sizable. The gap between the negligible liquidation elasticity of each bank and the sizable macro deleveraging elasticity manifests itself in the fire-sale congestion externality.

Aizenman (2009) shows that, if the only policy applied is a borrowing tax, then the optimal tax needed to induce banks to internalize the fire-sale externality is

$$
t=\theta n \cdot \eta_{\theta, i} \frac{E\left[z M P_{K_{2}} \mid Z>R\right]}{1+r_{f}} .
$$

The tax equals the externality $\left[\theta n \cdot \eta_{\theta, i}\right]$, times the expected cost of deleveraging pressure when $Z>R$, measured in terms of the marginal productivity of capital (i.e., $\left.E\left[z M P_{K_{2}} \mid Z>R\right]\right)$.

The borrowing tax policy stated in (2) may fall short of inducing the optimal demand for IR. Achieving optimal borrowing and hoarding reserves requires two policy instruments - an external borrowing tax (t) and an IR subsidy (s), given by:

$s=\theta n \cdot \eta_{\theta, i} \frac{E\left[M P_{K_{2}} \mid Z>R\right]}{\left(1+r_{f}\right) \operatorname{Pr}[Z<R]} ; \quad t=\theta n \cdot \eta_{\theta, i} \frac{E\left[z M P_{K_{2}} \mid Z>R\right]-s\left(1+r_{f}\right) E[z \mid Z<R]}{1+r_{f}}$.

It can be shown that the net tax revenue collected by the authorities is positive:

$$
t\left(1+r_{f}\right) D-s\left(1+r_{f}\right) \int_{0}^{z^{*}}(R-z D) f(z) d z=\theta n \cdot \eta_{\theta, i} E\left[(Z-R) M P_{K_{2}} \mid Z>R\right]>0 .
$$

The net tax revenue equals the product of the fire-sale externality $\left[\theta n \cdot \eta_{\theta, i}\right]$, times the expected liquidation costs in states where $Z>R, E\left[(Z-R) M P_{K_{2}} \mid Z>R\right]$. While subsidizing hoarding IR is costly, Eq. 4 shows that the fiscal revenue from the borrowing tax exceeds the cost of funding the hoarding subsidy. 
Open Access This article is distributed under the terms of the Creative Commons Attribution Noncommercial License which permits any noncommercial use, distribution, and reproduction in any medium, provided the original author(s) and source are credited.

\section{References}

Aizenman J (2004) Financial opening: evidence and policy options. In: Baldwin R, Winters A (eds) Challenges to globalization. University of Chicago Press, Chicago and London

Aizenman J (2009) Hoarding international reserves versus a Pigovian Tax-Cum-Subsidy scheme: reflections on the deleveraging crisis of 2008-9, and a cost benefit analysis. NBER Working Paper No. 15484

Aizenman J, Lee J (2007) International reserves: precautionary versus mercantilist views, theory and evidence. Open Econ Rev 18(2):191-214

Aizenman J, Marion N (1993) Policy uncertainty, persistence and growth. Rev Int Econ 1(9):145-163

Aizenman J, Pinto B (2005) Overview - Managing volatility and crises: a practitioner's guide. In: Aizenman J, Pinto B (eds) Chapter 1 in Managing economic volatility and crises: a practitioner's guide. Cambridge University Press, Cambridge

Aizenman J, Yi S (2009) The financial crisis and sizable international reserves depletion: from 'fear of floating' to the 'fear of losing international reserves'? NBER Working Paper No. 15308, forthcoming. J Macroecon

Aizenman J, Lee Y, Rhee Y (2007) International reserves management and capital mobility in a volatile world: policy considerations and a case study of Korea. J Jpn Int Econ 21(1):1-15

Bernanke B, Gertler M (1989) Agency costs, net worth, and business fluctuations. Am Econ Rev 79 (1): $14-31$

Bhattacharya S, Gale D (1987) Preference shocks, liquidity and central bank policy. In: Barnett WA, Singleton KJ (eds) New approaches to monetary economics. Cambridge University Press, Cambridge

Bryant J (1980) A model of reserves, bank runs, and deposit insurance. J Bank Financ 4:335-344

Caballero R, Krishnamurthy A (2004) Smoothing sudden stops. J Econ Theory 119(1):104-127

Calvo GA (2006) Monetary policy challenges in emerging markets: sudden stop, liability dollarization, and lender of last resort. Working Paper 12788, National Bureau of Economic Research

Calvo AG, Reinhart CM (2002) Fear of floating. Q J Econ 107(2):379-408

Cerra V, Saxena SC (2008) Growth dynamics: the myth of economic recovery. Am Econ Rev, Am Econ Assoc 98(1):439-457

Cheung Y-W, Qian X (2009) Hoarding of international reserves: Mrs Machlup's wardrobe and the Joneses. Rev Int Econ 17(4):777-801

Cowan K, De Gregorio J (2005) International borrowing, capital controls and the exchange rate: lessons from Chile. NBER Working paper 11382, National Bureau of Economic Research, Cambridge, MA

Diamond D, Dybvig P (1983) Bank runs, liquidity and deposit insurance. J Polit Econ 91:401-419

Dooley MP, Folkerts-Landau D, Garber P (2009) Bretton Woods II still defines the international monetary system. NBER Working Paper No. 14731

Edwards S (2000) Capital flows, real exchange rates and capital controls: some Latin American experiences. In: Edwards S (ed) Capital flows and the emerging economies. University of Chicago Press, Chicago, pp 197-253

Eichengreen B, Hausmann R, Panizza U (2003) Currency mismatches, debt intolerance and original sin: why they are not the same and why it matters. Working Paper 10036

Goodhart CAE (2009) Liquidity management. Comments on policies to stabilize financial markets, deliver at the Jackson Hole Symposium, Kansas City Fed

Holmstrom B, Tirole J (1998) Private and public supply of liquidity. J Polit Econ 106:1-40

Jeanne O (2007) International Reserves in Emerging Market Countries: Too Much of a Good Thing? Brookings Papers on Economic Activity, 2007:1, pp 1-55

Jeanne O, Ranciere R (2005) The optimal level of international reserves for emerging market economies: formulas and applications. IMF Research Department, May

Krugman P (2000) Fire-sale FDI. In: Edwards S (ed) Flows and the emerging economies: theory, evidence, and controversies. University of Chicago Press, Chicago and London, pp 43-60

Levi Yeyati E (2008) Liquidity insurance in a financially dollarized economy. In: Edwards S, Garcia MGP (eds) Financial markets volatility and performance in emerging markets. National Bureau of Economic Research. University of Chicago Press, Chicago and London, pp 185-218

Lucas RE Jr (1987) Models of business cycles. 1985 Yrjö Jahnsson Lectures. Blackwell, Oxford

Lucas RE Jr (2003) Macroeconomic priorities. Am Econ Rev 93(1):1-14 
Obstfeld M, Shambaugh JC, Taylor AM (2008) Financial stability, the trilemma, and international reserves. CEPR Discussion Paper 6693

Park YC (2009) Reform of the Global Regulatory System: Perspectives of East Asia's Emerging Economies. Presented that the ABCDE World Bank conference, Seoul, June 2009

Rajan RS, Siregar R, Bird G (2005) The precautionary demand for reserve holdings in Asia: examining the case for a regional reserve pool. Asia Pac J Econ Bus 5(12):21-39

Ramey G, Ramey VA (1995) Cross-country evidence on the link between volatility and growth. Am Econ Rev 85(5):1138-1151

Rodrik D (2006) The social cost of foreign exchange reserves. Int Econ J 20:3

Taylor JB (1993) Discretion versus policy rules in practice. Carnegie-Rochester Conf Ser Public Policy 39:195-214

Townsend RM (1979) Optimal contracts and competitive markets with costly state verification. J Econ Theory 22:265-293 